Annual Groundwater Detection
Monitoring Report for the Idaho
CERCLA Disposal Facility (2008)

July 2009 
DOE/ID-11403

Revision 0

\section{Annual Groundwater Detection Monitoring Report for the Idaho CERCLA Disposal Facility (2008)}

July 2009

Prepared for the 


\section{ABSTRACT}

This report presents the data collected for groundwater detection monitoring at the Idaho Comprehensive Environmental Response, Compensation and Liability Act (CERCLA) Disposal Facility (ICDF) during calendar year 2008.

The detection-monitoring program developed for the ICDF groundwater-monitoring wells is applicable to six wells completed in the uppermost portion of the Snake River Plain Aquifer - five wells downgradient of the ICDF and one well upgradient. The ICDF detection-monitoring program was established to meet the substantive requirements of Title 40 Code of Federal Regulations (CFR) Parts 264.97 and 264.98, which are applicable or relevant and appropriate requirements under CERCLA.

Semiannual groundwater samples were collected and analyzed for indicator parameters in March and September. The indicator parameters focus on constituents that are found in higher concentrations in ICDF leachate than in groundwater (bicarbonate alkalinity, sulfate, U-233, U-234, and U-238).

The only detection monitoring limits that were exceeded were for bicarbonate alkalinity. Bicarbonate alkalinity is naturally occurring in groundwater. Bicarbonate alkalinity found in ICDF detection monitoring wells is not a result of waste migration from the ICDF landfill or the evaporation pond. The U.S. Department of Energy will continue with detection monitoring for the ICDF, which is semiannual sampling for indicator parameters. 


\section{CONTENTS}

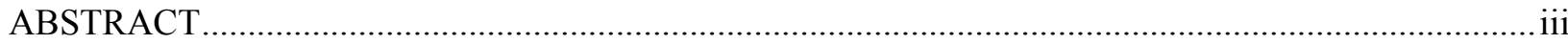

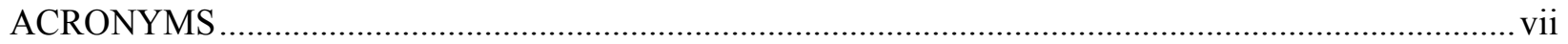

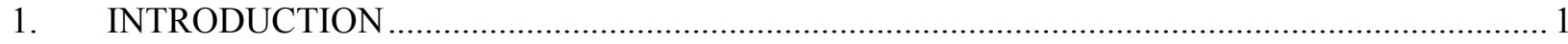

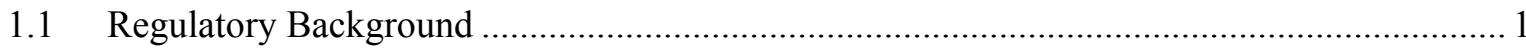

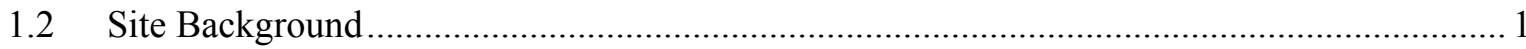

2. SNAKE RIVER PLAIN AQUIFER DETECTION MONITORING PROGRAM .......................... 4

2.1 Well Modifications and Sampling History …........................................................... 5

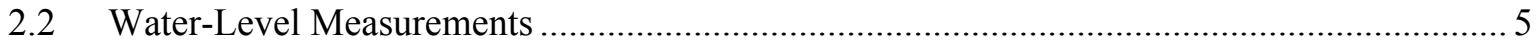

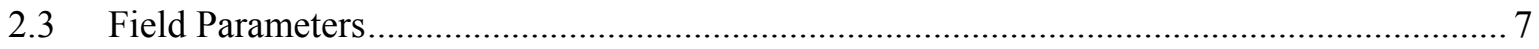

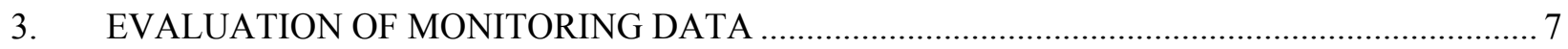

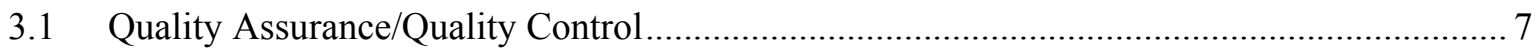

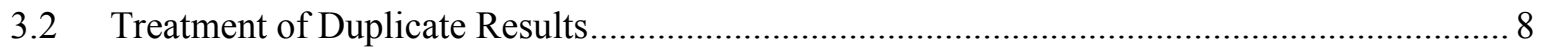

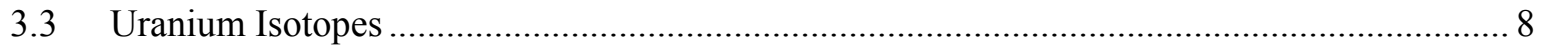

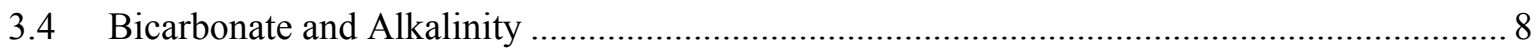

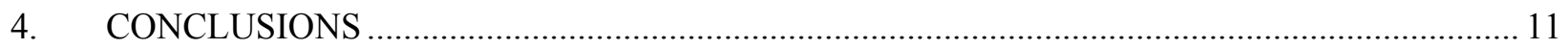

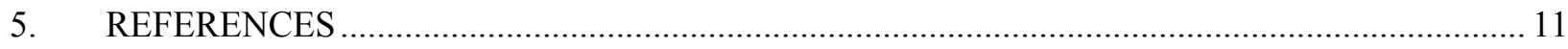

Appendix A-Hydrographs of ICDF Perched Water Wells for 2008 ............................................... A-1

Appendix B - Field Parameter Measurements from 2008 Sampling of ICDF Aquifer

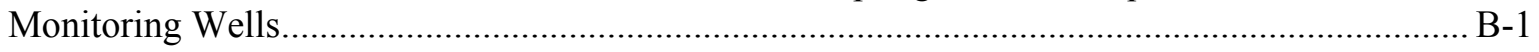

Appendix C-Analytical Results from 2008 Sampling of ICDF Aquifer Monitoring Wells.................. C-1 


\section{FIGURES}

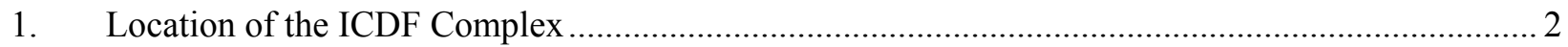

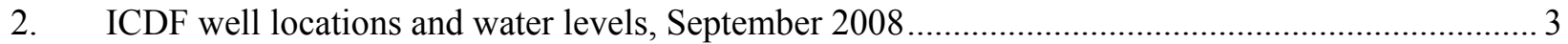

\section{TABLES}

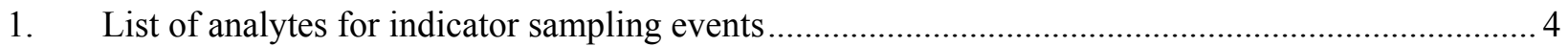

2. Groundwater levels measured in March and September 2008 ................................................... 5

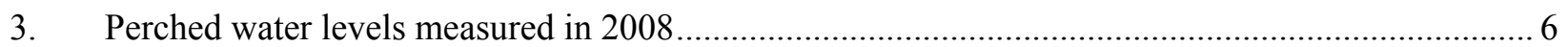

4. Detection monitoring limit and sample analysis results for $\mathrm{U}-233$ and $\mathrm{U}-234(\mathrm{pCi} / \mathrm{L})$................ 9

5. Detection monitoring limit and sample analysis results for $\mathrm{U}-238(\mathrm{pCi} / \mathrm{L})$............................ 9

6. Comparison of maximum sample results and detection monitoring limits for radionuclides ........... 9

7. Detection monitoring limits and sample analysis results for bicarbonate alkalinity

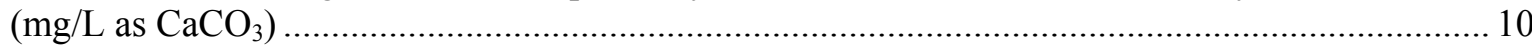

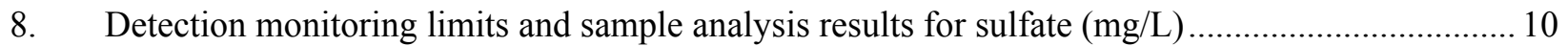

9. Comparison of maximum sample results and detection monitoring limits for bicarbonate alkalinity and sulfate. 


\section{ACRONYMS}

amsl above mean sea level

bgs below ground surface

CERCLA Comprehensive Environmental Response, Compensation and Liability Act

CFR Code of Federal Regulations

DML detection monitoring limit

DOE-ID Department of Energy Idaho Operations Office

ICDF Idaho CERCLA Disposal Facility

INL Idaho National Laboratory

INTEC Idaho Nuclear Technology and Engineering Center

MDA minimum detectable activity

OU operable unit

ROD Record of Decision

SRPA Snake River Plain Aquifer

WAG Waste Area Group 


\section{Annual Groundwater Detection Monitoring Report for the Idaho CERCLA Disposal Facility (2008)}

\section{INTRODUCTION}

This report summarizes the groundwater monitoring results for 2008 at the Idaho Comprehensive Environmental Response, Compensation and Liability Act (CERCLA) Disposal Facility (ICDF) near the Idaho Nuclear Technology and Engineering Center (INTEC) located at the Idaho National Laboratory (INL) Site.

\subsection{Regulatory Background}

The U.S. Department of Energy Idaho Operations Office (DOE-ID) authorized a remedial action for the INTEC in accordance with the Waste Area Group (WAG) 3, Operable Unit (OU) 3-13 Record of Decision (ROD) (DOE-ID 1999). The OU 3-13 ROD requires the removal and on-Site disposal of some of the CERCLA remediation wastes generated within the boundaries of the INL Site.

\subsection{Site Background}

The ICDF is an on-Site, engineered facility, located outside the southwest boundary of INTEC (Figure 1). The major components of the ICDF Complex include the following: landfill (originally consisting of two disposal cells); evaporation pond (consisting of two cells); administration trailer; scale; decontamination building with treatment area (not in use); contaminated equipment pad (not in use); and staging and storage areas. The ICDF groundwater-monitoring network consists of five Snake River Plain Aquifer wells downgradient of the ICDF and one upgradient well, USGS-123 (Figure 2). These wells meet the substantive requirements of Title 40 Code of Federal Regulations (CFR) Parts 264.97 and 264.98 that were designated as applicable or relevant and appropriate requirements under CERCLA in the OU 3-13 ROD. The first waste was placed in the ICDF landfill on September 16, 2003.

The ICDF Complex Groundwater Monitoring Plan (DOE-ID 2007) details the groundwater monitoring requirements associated with the ICDF, including monitoring wells, sample frequency, required analytes, laboratory analysis, fieldwork, and quality control. The INEEL CERCLA Disposal Facility Groundwater Detection Monitoring Program: Data Analysis Plan (DOE-ID 2003) (referred to as the Data Analysis Plan) details the approach used to evaluate the groundwater data collected in support of the ICDF detection-monitoring program. 


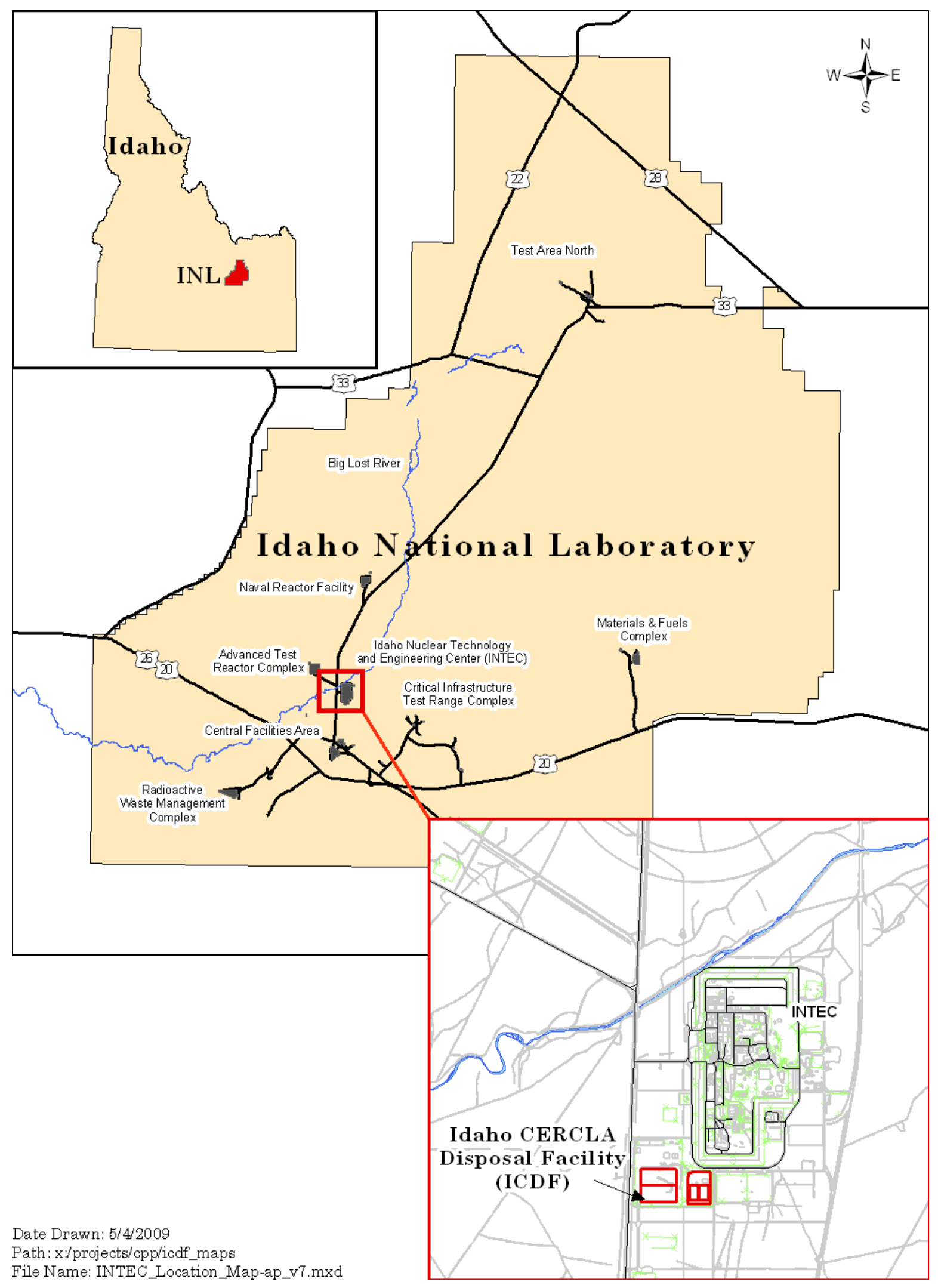

Figure 1. Location of the ICDF Complex. 


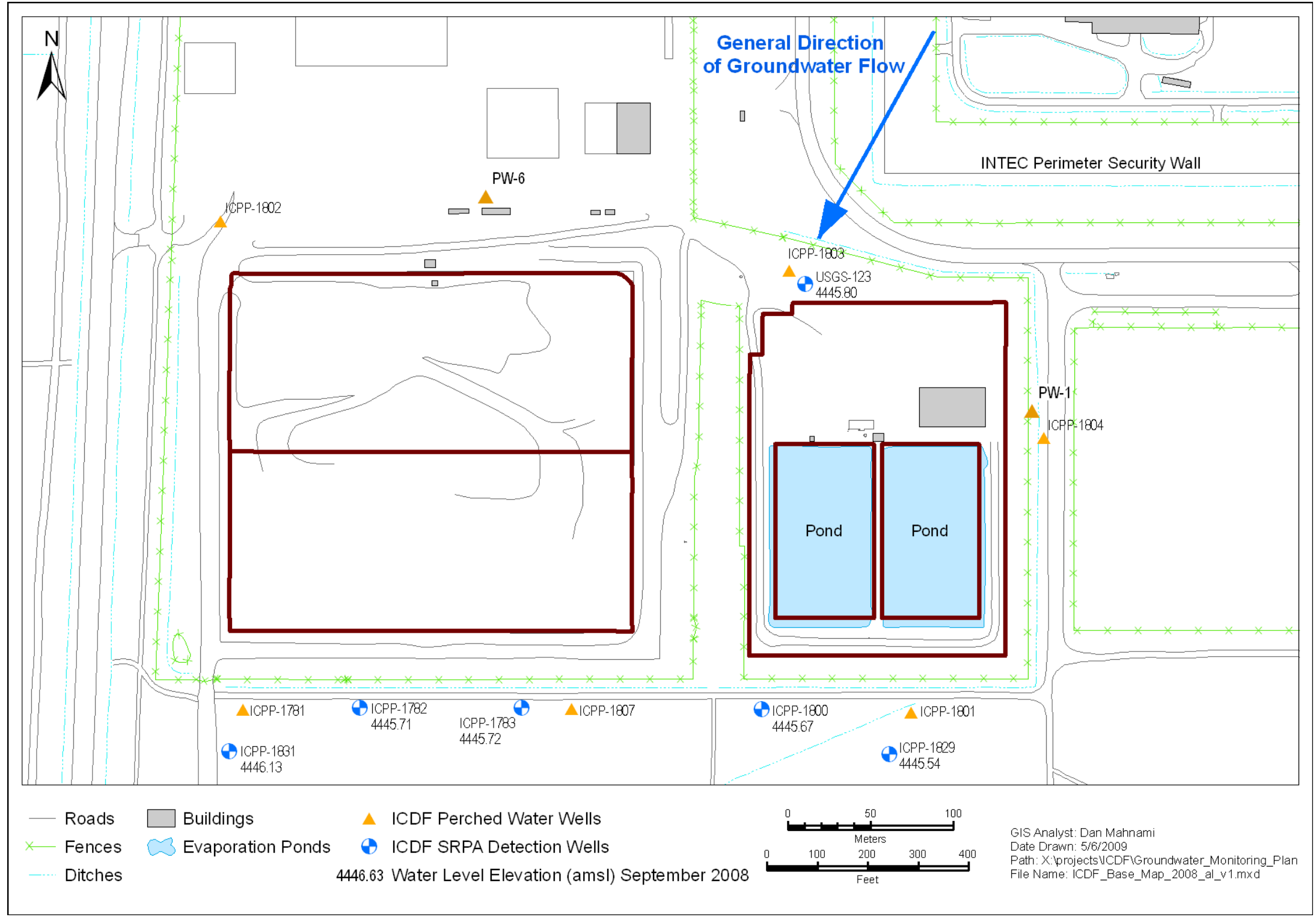

Figure 2. ICDF well locations and water levels, September 2008. 


\section{SNAKE RIVER PLAIN AQUIFER DETECTION MONITORING PROGRAM}

Detection monitoring is conducted at the ICDF to comply with the OU 3-13 ROD (DOE-ID 1999) requirements to meet the substantive portions that are applicable or relevant and appropriate in 40 CFR 264.98. Detection monitoring will continue unless there is statistically significant evidence of a release as defined in 40 CFR 264.98(f)(1). The detection-monitoring program developed for the ICDF groundwater monitoring wells is currently applicable to those six wells completed in the uppermost portion of the Snake River Plain Aquifer (SRPA). Detection monitoring does not include the investigation phase that will be conducted if statistically significant evidence is found that a release has occurred from the ICDF.

The ICDF detection-monitoring program has established the statistical methods that determine whether there is statistically significant evidence of contamination for any monitoring parameter at the ICDF SRPA wells. As stated above, these statistical methods are detailed in the Data Analysis Plan. Of the acceptable methods listed in 40 CFR 264.97(h), the ICDF detection-monitoring program will use either nonparametric prediction limits as allowed in 40 CFR 264.97(h)(3) or control charts as allowed in 40 CFR 264.97(h)(4) to evaluate the groundwater monitoring data for statistically significant evidence of contamination. Either method produces detection monitoring limits (DMLs); if a sample result exceeds the DML, there is statistically significant evidence of contamination.

As documented in the ICDF Complex Groundwater Monitoring Plan (DOE-ID 2007), the six SRPA wells are sampled semiannually for indicator parameters (Table 1).

Table 1. List of analytes for indicator sampling events.

\begin{tabular}{c} 
Analytes \\
\hline U-233, U-234, and U-238 \\
Bicarbonate alkalinity and sulfate \\
\hline
\end{tabular}

As agreed in the Data Analysis Plan and as part of the ongoing detection monitoring, the DMLs and methods selected for a given parameter/well will be evaluated every 2 years as recommended by the American Society of Testing and Materials (ASTM) D6312 to incorporate additional data obtained after ICDF startup. This evaluation will be performed after validation of the 2009 sampling results from two rounds of indicator sampling.

The Site-wide false-positive rate is the probability, given there is an exceedance of a DML at any well for any of the four indicator analytes, that the exceedance does not represent true contamination above background levels. The current individual false-positive rate is approximately $17 \%$ for bicarbonate alkalinity and sulfate and around $1 \%$ for U-233, U-234, and U-238. The major reason why the Site-wide false positive rate is higher for bicarbonate alkalinity and sulfate is because the DMLs are well-specific; therefore, they are based on fewer data points. When DMLs are recalculated, if results can be pooled across wells, then this rate will dramatically decrease. The false-positive rates for U-233/U-234 and U-238 are lower because they have combined control chart DMLs. The rate should continue to decrease as more data are collected. 


\subsection{Well Modifications and Sampling History}

There were no well modifications during 2008. Sampling and well history can be found in the Analysis of Baseline Data from ICDF Detection Monitoring Wells (INEEL 2006).

\subsection{Water-Level Measurements}

Water levels were measured in the six SRPA monitoring wells in March and September 2008 (Table 2). Water-level elevations ranged from 4,446 to 4,448 ft above mean sea level (amsl). The water levels are higher in March than in September.

Table 2. Groundwater levels measured in March and September 2008.

\begin{tabular}{lcc}
\hline Well Name & $\begin{array}{c}\text { March 2008 Water Level in } \mathrm{ft} \text { amsl } \\
\text { (Depth to water in ft bgs) }\end{array}$ & $\begin{array}{c}\text { September 2008 Water Level in ft amsl } \\
\text { (Depth to water in ft bgs) }\end{array}$ \\
\hline ICPP-1782 & 4446.96 & 4445.71 \\
& $(475.83)$ & $(477.08)$ \\
ICPP-1783 & 4446.98 & 4445.72 \\
& $(474.53)$ & $(475.79)$ \\
ICPP-1800 & 4446.86 & 4445.67 \\
& $(473.80)$ & $(474.99)$ \\
ICPP-1829 & 4446.76 & 4445.54 \\
& $(473.13)$ & $(474.35)$ \\
ICPP-1831 & 4447.93 & 4446.13 \\
& $(475.74)$ & $(477.54)$ \\
USGS-123 & 4447.19 & 4445.80 \\
& $(471.99)$ & $(473.38)$ \\
\hline Amsl above mean sea level & & \\
bgs & & \\
\hline
\end{tabular}

Perched water monitoring wells are installed around the ICDF as shown in Figure 2. Perched water wells were checked for the presence of perched water prior to each sampling event. Where perched water was present, water levels were measured, although it is difficult to get an accurate estimate of the height of the water column in the wells due to the small amount of water in the wells and the presence of mud. The results are shown in Table 3 . The only well that consistently had water in it in 2008 was ICPP-1804M, which had between 0.09 and $0.3 \mathrm{ft}$ of water in it (see hydrograph in Appendix A). There are transducers in the westernmost wells (ICPP-1802U, ICPP-1802L, ICPP-1781U, ICPP-1781M, and ICPP-1781L). The transducers recorded no water in the three completions in ICPP-1781 (U, M, or L) or in ICPP-1802U, although presence of water was occasionally detected manually (e.g., $0.04 \mathrm{ft}$ of water in ICPP-1802U in February). 
Appendix A contains a hydrograph for perched water well ICPP-1802L. The fluctuations in water levels in ICPP-1802L are attributed to barometric pressure. The apparent shift in water levels in August 2008 is due to the barometric pressure sensor. The battery was failing, and a new barometric pressure sensor began recording in August. As was shown in the biennial monitoring report (DOE-ID 2008a), the well exhibits close to $100 \%$ barometric efficiency with an approximate 1-day lag. The well was checked manually three times in 2008. In February, the well only contained mud. In June, approximately $1.65 \mathrm{ft}$ of water was found in the well above the mud. In August, approximately $1.49 \mathrm{ft}$ of water was found above the mud. ICPP-1781U and ICPP-1807L had just enough moisture to record on the electronic water-level indicator in February, but insufficient water to measure any height for a water column (i.e., electronic water-level indicator sounded on the bottom of the well).

Table 3. Perched water levels measured in 2008.

\begin{tabular}{|c|c|c|}
\hline Well Name & $\begin{array}{l}\text { Measurement Dates } \\
\text { (Manual Water Levels) }\end{array}$ & $\begin{array}{c}\text { Depth to Water in } \mathrm{ft} \text { bgs } \\
\text { (ft of water) }\end{array}$ \\
\hline ICPP-1781 Lower & $\begin{array}{l}2 / 19 / 2008 \\
6 / 5 / 2008 \\
8 / 20 / 2008\end{array}$ & $\begin{array}{l}\text { Dry } \\
\text { Dry } \\
\text { Dry }\end{array}$ \\
\hline ICPP-1781 Middle & $\begin{array}{l}2 / 19 / 2008 \\
6 / 5 / 2008 \\
8 / 20 / 2008\end{array}$ & $\begin{array}{l}\text { Dry } \\
\text { Dry } \\
\text { Dry }\end{array}$ \\
\hline ICPP-1781 Upper & $\begin{array}{l}2 / 19 / 2008 \\
6 / 5 / 2008 \\
8 / 20 / 2008\end{array}$ & $\begin{array}{c}175.26 \text { (Dry by transducer) } \\
\text { Dry } \\
\text { Dry }\end{array}$ \\
\hline ICPP-1801 Middle & $\begin{array}{l}2 / 19 / 2008 \\
8 / 20 / 2008\end{array}$ & $\begin{array}{l}\text { Dry } \\
\text { Dry }\end{array}$ \\
\hline ICPP-1801 Upper & $\begin{array}{l}2 / 19 / 2008 \\
8 / 20 / 2008\end{array}$ & $\begin{array}{l}\text { Dry } \\
\text { Dry }\end{array}$ \\
\hline ICPP-1802 Lower & $\begin{array}{l}2 / 19 / 2008 \\
6 / 5 / 2008 \\
8 / 20 / 2008\end{array}$ & $\begin{array}{c}\text { Dry } \\
378.22(1.65) \\
378.32(1.49)\end{array}$ \\
\hline ICPP-1802 Upper & $\begin{array}{l}2 / 19 / 2008 \\
6 / 5 / 2008 \\
8 / 20 / 2008\end{array}$ & $\begin{array}{l}206.45(0.04) \\
\text { Dry } \\
\text { Dry }\end{array}$ \\
\hline ICPP-1803 Lower & $\begin{array}{l}2 / 19 / 2008 \\
8 / 20 / 2008\end{array}$ & $\begin{array}{l}\text { Dry } \\
\text { Dry }\end{array}$ \\
\hline ICPP-1803 Middle & $\begin{array}{l}2 / 19 / 2008 \\
8 / 20 / 2008\end{array}$ & $\begin{array}{l}\text { Dry } \\
\text { Dry }\end{array}$ \\
\hline ICPP-1803 Upper & $\begin{array}{l}2 / 19 / 2008 \\
8 / 20 / 2008\end{array}$ & $\begin{array}{c}108.45(0.12 \mathrm{ft}) \\
\text { Dry }\end{array}$ \\
\hline ICPP-1804 Lower & $\begin{array}{l}2 / 19 / 2008 \\
6 / 5 / 2008 \\
8 / 20 / 2008\end{array}$ & $\begin{array}{l}377.48(0.40) \\
377.22 \\
\text { Dry }\end{array}$ \\
\hline
\end{tabular}


Table 3. (continued).

\begin{tabular}{lcc} 
Well Name & $\begin{array}{c}\text { Measurement Dates } \\
\text { (Manual Water Levels) }\end{array}$ & $\begin{array}{c}\text { Depth to Water in ft bgs } \\
\text { (ft of water) }\end{array}$ \\
\hline ICPP-1804 Middle & $2 / 19 / 2008$ & $265.73(0.30)$ \\
& $6 / 5 / 2008$ & 265.78 \\
& $8 / 20 / 2008$ & $265.78(0.09)$ \\
ICPP-1807 Lower & $2 / 19 / 2008$ & $384.6($ trace) \\
& $8 / 20 / 2008$ & Dry \\
ICPP-1807 Middle & $2 / 19 / 2008$ & Dry \\
& $8 / 20 / 2008$ & Dry \\
ICPP-1807 Upper & $2 / 19 / 2008$ & Dry \\
& $8 / 20 / 2008$ & Dry \\
PW-1 & $2 / 19 / 2008$ & Not measured due to ice obstruction \\
& $8 / 20 / 2008$ & Dry \\
PW-6 & $2 / 19 / 2008$ & Dry \\
& $8 / 20 / 2008$ & Dry \\
\hline bgs below ground surface & & \\
\hline
\end{tabular}

\subsection{Field Parameters}

Field parameters ( $\mathrm{pH}$, specific conductivity, and temperature) are measured immediately prior to sampling each well. These parameters are measured by the field sampling team as required in the ICDF Complex Groundwater Monitoring Plan (DOE-ID 2007) and are recorded in the field-sampling logbook. Field parameters are measured before taking the water sample and are used to determine when a sample can be collected. The field parameters are included in Appendix B.

\section{EVALUATION OF MONITORING DATA}

Data from routine detection monitoring were compared to DMLs for each well and each of the required constituents (Table 1). As specified in the Data Analysis Plan, before using any monitoring data, they were evaluated with respect to any impacts from validation (i.e., rejected results), nondetected results, and duplicate sample results per sampling round. All sampling results are tabulated in Appendix C.

\subsection{Quality Assurance/Quality Control}

All rounds of sampling and analysis followed established procedures and analytical methodologies. Two rounds of samples for indicator parameters were collected in March and September 2008. The completeness goal for the project of $100 \%$ was met. All of the data are acceptable.

Laboratories on the CWI Qualified Suppliers List performed all analyses. The ICDF Complex Groundwater Monitoring Plan (DOE-ID 2007) required one duplicate and field blank for every 20 samples collected or, at a minimum, $5 \%$ of the total number of samples collected. The actual percentage of duplicates and blanks was higher, because the number of wells sampled during each round was much less than 20. 
The radioanalytical results were U-flagged by the data validator for reported data less than minimum detectable activity (MDA) (i.e., no detectable activity) or J-flagged if radioactivity was detected, but due to analytical and/or laboratory quality control issues, the reported quantity was considered an estimate. As shown in Appendix C (Table C-1), one field blank was flagged U and the other was flagged $\mathrm{J}$ by the data validator. For U-238, both field blanks were flagged $\mathrm{U}$ by the data validator.

For bicarbonate alkalinity and sulfate analyses, a $\mathrm{J}$ flag from the laboratory means that the material was analyzed for, was detected at or above the applicable detection limit, and the associated value is an estimate that may be inaccurate or imprecise. A U flag from the laboratory means that the material was not detected. The two field blanks for sulfate were flagged $U$ by the laboratory (not detected), and one of the field blanks for bicarbonate alkalinity was flagged $\mathrm{J}$ by the laboratory and flagged $\mathrm{U}$ by the data validator to denote the data are nondetect at the reported value due to a positive blank detection as shown in Appendix C (Table C-2).

\subsection{Treatment of Duplicate Results}

When duplicate results existed, the maximum detected result was used for comparison to DMLs. All duplicate results are presented in Appendix C.

\subsection{Uranium Isotopes}

For U-233 and U-234, none of the data from the monitoring wells was flagged, as shown in Table 4. Four of the monitoring well results for U-238 were flagged J during the September sampling round by the data validator, as shown in Table 5.

The maximum result and DMLs for the $\mathrm{U}$ isotopes are presented in Table 6 and all monitoring results are presented in Appendix C (Table C-1). All results for U isotopes were below the DMLs.

\subsection{Bicarbonate and Alkalinity}

For bicarbonate alkalinity and sulfate analyses, none of the sample results from the monitoring wells were flagged, as shown in Tables 7 and 8. All monitoring results are presented in Appendix C (Table C-2). The maximum results and DMLs are presented in Table 9. Bicarbonate exceeded the DML in three wells (ICPP-1783, ICPP-1800, and ICPP-1831 [duplicate exceeded DML, sample did not]). Bicarbonate alkalinity is not attributable to ICDF operations because the concentrations measured in the detection monitoring wells are within the range of naturally occurring bicarbonate alkalinity levels found in the SRPA upgradient of the ICDF. During the 2007 WAG 3 sampling, bicarbonate alkalinity ranged from 139 to $226 \mathrm{mg} / \mathrm{L}$ in INTEC wells located upgradient of the ICDF (DOE-ID 2008b). In addition, the leak detection systems at the ICDF do not indicate that the landfill or evaporation ponds have leaked. 
Table 4. Detection monitoring limit and sample analysis results for U-233 and U-234 (pCi/L). (Field duplicate results in parentheses.)

\begin{tabular}{|l|l|c|c|c|c|c|c|}
\hline \multicolumn{2}{|c|}{ Wells } & ICPP-1782 & ICPP-1783 & ICPP-1800 & ICPP-1829 & ICPP-1831 & USGS-123 \\
\hline \multicolumn{2}{|l|}{ Detection Monitoring Limit } & 2.66 & $\begin{array}{c}1.85 \pm 0.26 \\
(1.95 \pm 0.27)\end{array}$ & $1.7 \pm 0.2$ & $1.32 \pm 0.20$ & $1.34 \pm 0.20$ & $1.89 \pm 0.25$ \\
\hline $\begin{array}{l}\text { Sample Analysis } \\
\text { Results }\end{array}$ & $3 / 4 / 08$ & $1.8 \pm 0.4$ & $1.77 \pm 0.43$ & $1.63 \pm 0.39$ & $1.72 \pm 0.43$ & $\begin{array}{c}2.11 \pm 0.46 \\
(1.89 \pm 0.43)\end{array}$ \\
\cline { 2 - 7 } & $9 / 8 / 08$ and 9/9/08 & & & & $1.5 \pm 0.4$ \\
\hline
\end{tabular}

Table 5. Detection monitoring limit and sample analysis results for $\mathrm{U}-238$ (pCi/L). (Field duplicate results in parentheses.)

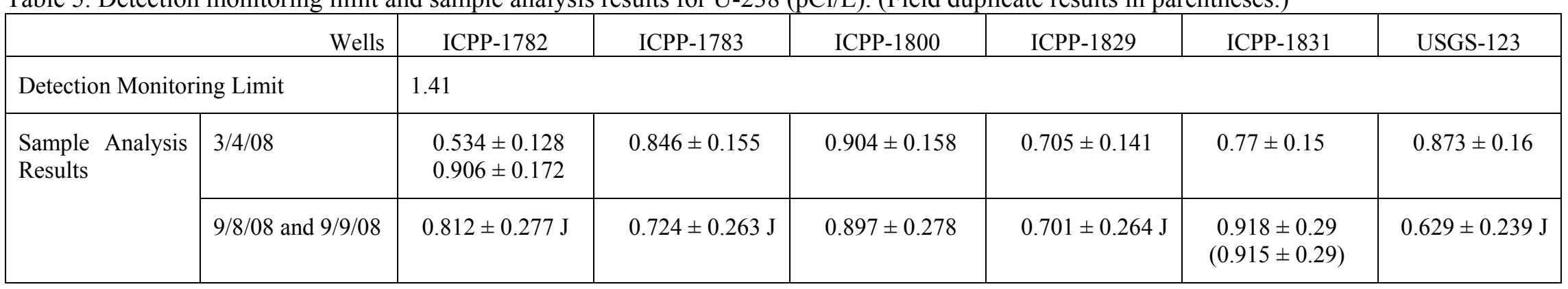

Table 6. Comparison of maximum sample results and detection monitoring limits for radionuclides.

\begin{tabular}{|c|c|c|c|c|c|c|c|c|c|}
\hline \multirow[b]{2}{*}{ Radionuclide } & \multirow{2}{*}{$\begin{array}{c}\text { Number of } \\
\text { Available } \\
\text { Monitoring } \\
\text { Results } \\
\end{array}$} & \multirow{2}{*}{$\begin{array}{l}\text { Number of } \\
\text { Nondetected/ } \\
\text { Detected } \\
\text { Results } \\
\end{array}$} & \multirow{2}{*}{$\begin{array}{c}\text { Maximum Detected } \\
\text { Result / DML Over } \\
\text { All Wells } \\
(\mathrm{pCi} / \mathrm{L})\end{array}$} & \multicolumn{6}{|c|}{ Maximum Detected Result / Well-Specific DML } \\
\hline & & & & $\begin{array}{c}\text { ICPP-1782 } \\
(\mathrm{pCi} / \mathrm{L})\end{array}$ & $\begin{array}{c}\text { ICPP-1783 } \\
(\mathrm{pCi} / \mathrm{L})\end{array}$ & $\begin{array}{c}\text { ICPP-1800 } \\
(\mathrm{pCi} / \mathrm{L})\end{array}$ & $\begin{array}{c}\text { ICPP-1829 } \\
(\mathrm{pCi} / \mathrm{L})\end{array}$ & $\begin{array}{c}\text { ICPP-1831 } \\
(\mathrm{pCi} / \mathrm{L})\end{array}$ & $\begin{array}{c}\text { USGS-123 } \\
(\mathrm{pCi} / \mathrm{L})\end{array}$ \\
\hline $\mathrm{U}-233$ and 234 & 12 & $0 / 12$ & $2.11 / 2.66$ & - & - & - & - & - & - \\
\hline $\mathrm{U}-238$ & 12 & $0 / 12$ & $0.918 / 1.410$ & - & - & - & - & - & - \\
\hline
\end{tabular}


Table 7. Detection monitoring limits and sample analysis results for bicarbonate alkalinity $\left(\mathrm{mg} / \mathrm{L}\right.$ as $\mathrm{CaCO}_{3}$ ). (Field duplicate results in parentheses.)

\begin{tabular}{|l|l|c|c|c|c|c|c|}
\hline \multicolumn{2}{|r|}{ Wells } & ICPP-1782 & ICPP-1783 & ICPP-1800 & ICPP-1829 & ICPP-1831 & USGS-123 \\
\hline \multicolumn{2}{|l|}{ Detection Monitoring Limits } & 152 & 146 & 138 & 139 & 153 & 145 \\
\hline $\begin{array}{l}\text { Sample Analysis } \\
\text { Results }\end{array}$ & $3 / 4 / 08$ & $152(150)$ & $\mathbf{1 4 8}$ & $\mathbf{1 4 1}$ & 132 & $\mathbf{1 5 4}$ \\
\cline { 2 - 8 } & $9 / 8 / 08$ and 9/9/08 & 152 & $\mathbf{1 5 1}$ & $\mathbf{1 3 9}$ & 132 & $153(\mathbf{1 5 5})$ & 133 \\
\hline
\end{tabular}

Table 8. Detection monitoring limits and sample analysis results for sulfate $(\mathrm{mg} / \mathrm{L})$. (Field duplicate results in parentheses.)

\begin{tabular}{|l|l|c|c|c|c|c|c|}
\hline \multicolumn{2}{|r|}{ Wells } & ICPP-1782 & ICPP-1783 & ICPP-1800 & ICPP-1829 & ICPP-1831 & USGS-123 \\
\hline \multicolumn{2}{|l|}{ Detection Monitoring Limits } & 27.6 & 28.5 & 29.4 & 32.5 & 26 & 29.3 \\
\hline $\begin{array}{l}\text { Sample Analysis } \\
\text { Results }\end{array}$ & $3 / 4 / 08$ & $22.4(22.5)$ & 24.2 & 25.6 & 27.4 & 22.2 & 20 \\
\cline { 2 - 8 } & $9 / 8 / 08$ and 9/9/08 & 24.4 & 26.3 & 27.7 & 29.2 & $24.5(24.7)$ & 22 \\
\hline
\end{tabular}

Table 9. Comparison of maximum sample results and detection monitoring limits for bicarbonate alkalinity and sulfate. Bold entries indicate maximum 2008 result exceeds DML.

\begin{tabular}{|c|c|c|c|c|c|c|c|c|}
\hline \multirow[b]{2}{*}{ Radionuclide } & \multirow{2}{*}{$\begin{array}{c}\text { Number of } \\
\text { Available } \\
\text { Monitoring } \\
\text { Results }\end{array}$} & \multirow{2}{*}{$\begin{array}{l}\text { Number of } \\
\text { Nondetected/ } \\
\text { Detected } \\
\text { Results }\end{array}$} & \multicolumn{6}{|c|}{ Maximum Detected Result / Well-Specific DML } \\
\hline & & & $\begin{array}{c}\text { ICPP-1782 } \\
(\mathrm{mg} / \mathrm{L})\end{array}$ & $\begin{array}{c}\text { ICPP-1783 } \\
(\mathrm{mg} / \mathrm{L})\end{array}$ & $\begin{array}{c}\text { ICPP-1800 } \\
(\mathrm{mg} / \mathrm{L})\end{array}$ & $\begin{array}{c}\text { ICPP-1829 } \\
(\mathrm{mg} / \mathrm{L})\end{array}$ & $\begin{array}{c}\text { ICPP-1831 } \\
(\mathrm{mg} / \mathrm{L})\end{array}$ & $\begin{array}{c}\text { USGS-123 } \\
(\mathrm{mg} / \mathrm{L})\end{array}$ \\
\hline Bicarbonate & & $0 / 12$ & $152 / 152$ & $151 / 146$ & $141 / 138$ & $132 / 139$ & $155 / 153$ & $133 / 145$ \\
\hline Sulfate & & $0 / 12$ & $24.4 / 27.6$ & $26.3 / 28.5$ & $27.7 / 29.4$ & $29.2 / 32.5$ & $24.7 / 26$ & $22 / 29.3$ \\
\hline
\end{tabular}




\section{CONCLUSIONS}

Semiannual sampling of the ICDF detection monitoring network for indicator parameters during 2008 resulted in bicarbonate alkalinity exceeding the DMLs in three downgradient wells. The sampling results for all other indicator parameters were below the DMLs. Bicarbonate alkalinity is not attributable to ICDF operations because the concentrations measured in the detection monitoring wells are within the range of naturally occurring bicarbonate alkalinity levels found in the Snake River Plain Aquifer upgradient of the ICDF. In addition, the leak detection systems at the ICDF do not indicate that the landfill or evaporation ponds have leaked. This report meets the substantive requirements of 40 CFR $264.98(\mathrm{~g})$ to demonstrate that the contamination is not due to waste migration from the ICDF landfill or evaporation pond. DOE will continue with the detection monitoring for the ICDF, which is semiannual sampling for indicator parameters.

\section{REFERENCES}

40 CFR 264.97, 2000, "General Ground-Water Monitoring Requirements," Code of Federal Regulations, Office of the Federal Register, July 2000.

40 CFR 264.98, 2000, "Detection Monitoring Program," Code of Federal Regulations, Office of the

DOE-ID, 1999, Final Record of Decision Idaho Nuclear Technology and Engineering Center, Operable Unit 3-13, DOE/ID-10660, Rev. 0, U.S. Department of Energy Idaho Operations Office, October 1999.

DOE-ID, 2003, INEEL CERCLA Disposal Facility Groundwater Detection Monitoring Program: Data Analysis Plan, DOE/ID-10998, Rev. 0, U.S. Department of Energy Idaho Operations Office, February 2003.

DOE-ID, 2007, ICDF Complex Groundwater Monitoring Plan, DOE/ID-10955, Rev. 5, U.S. Department of Energy Idaho Operations Office, August 2007.

DOE-ID, 2008a, ICDF Detection Monitoring Biennial Report (2006-2007), DOE/ID-11373, Rev. 0, U.S. Department of Energy Idaho Operations Office, July 2008.

DOE-ID, 2008b, INTEC Groundwater Monitoring Report (2007), DOE/ID-11356, Rev. 1, U.S. Department of Energy Idaho Operations Office, June 2008.

INEEL, 2006, Analysis of Baseline Data from ICDF Detection Monitoring Wells, INEEL/EXT-03-00251, Rev. 1, Idaho Cleanup Project, June 2006. 
Appendix A

Hydrographs of ICDF Perched Water Wells for 2008 


$$
\text { A-2 }
$$




\section{Appendix A}

Hydrographs of ICDF Perched Water Monitoring Wells for 2008

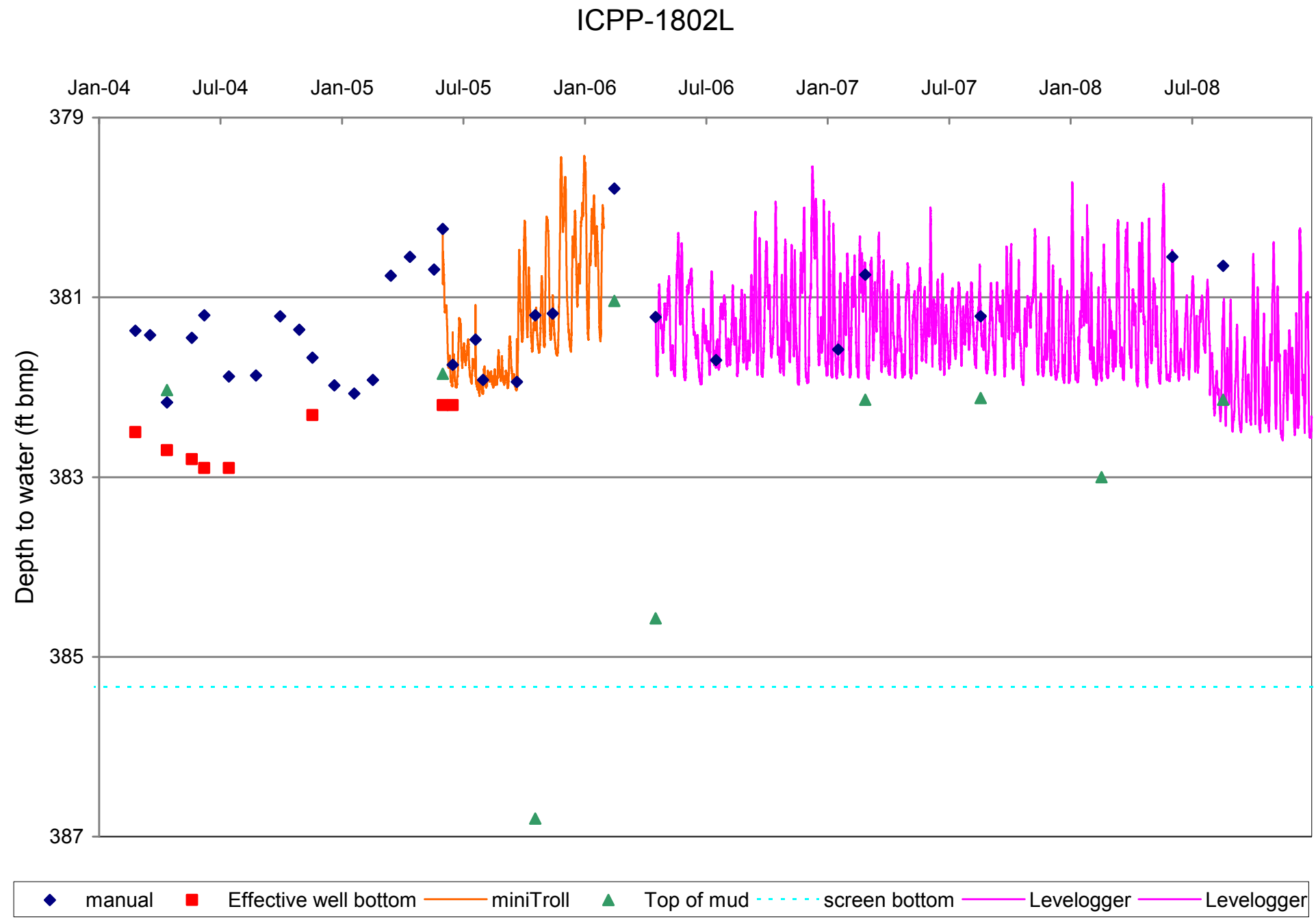

Figure A-1. Hydrograph for ICPP-1802L. 


\section{Water Levels in ICPP-1804M}

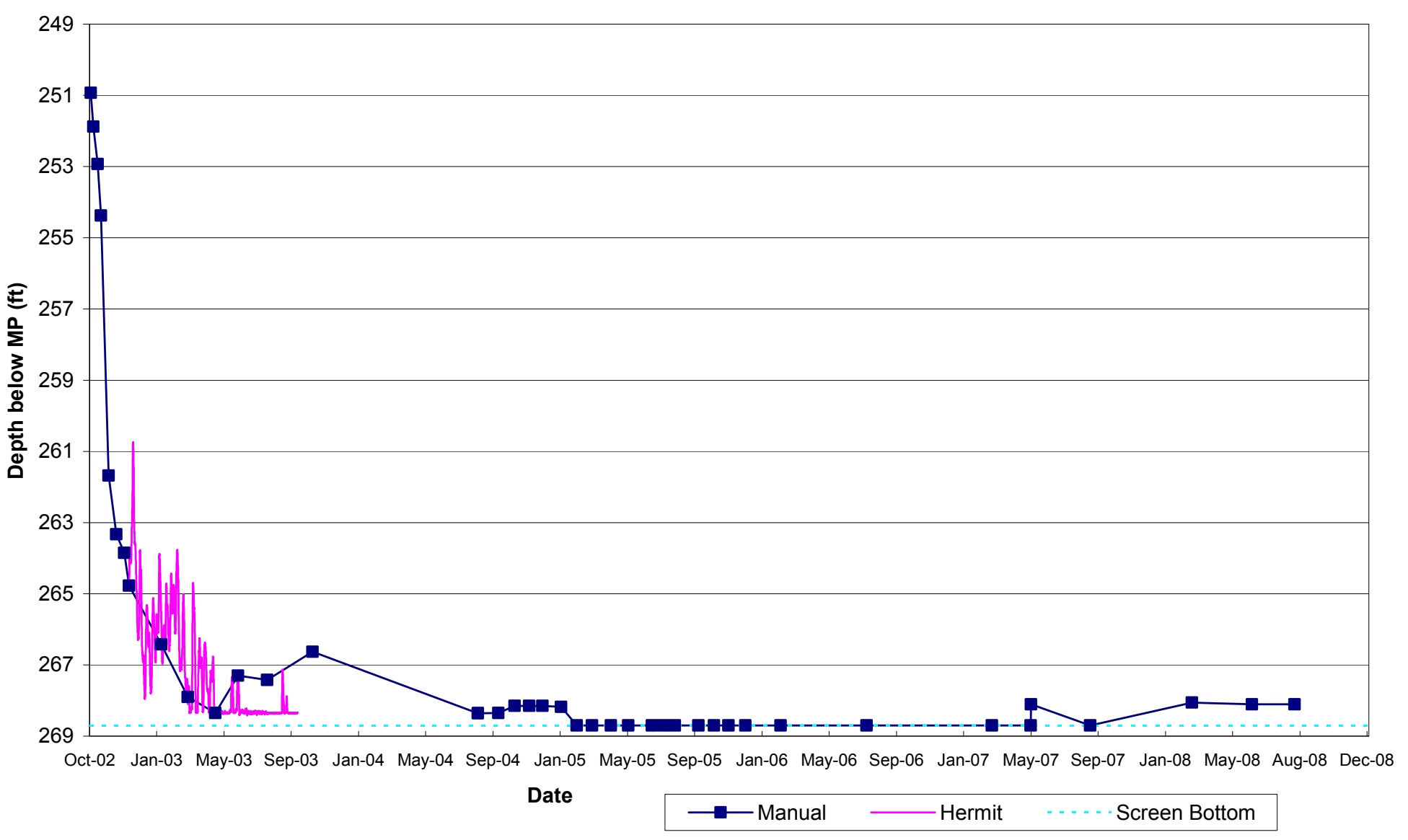

Figure A-2. Hydrograph for ICPP-1804M. 


\section{Appendix B}

Field Parameter Measurements from 2008 Sampling of ICDF Aquifer Monitoring Wells 
B-2 


\section{Appendix B}

\section{Field Parameter Measurements from 2008 Sampling of ICDF Aquifer Monitoring Wells}

Table B-1. Field parameter measurements.

\begin{tabular}{|c|c|c|c|c|}
\hline Location & Parameter & Date Collected & Result & Units \\
\hline ICPP-1782 & $\mathrm{pH}$ & $3 / 4 / 2008$ & 7.68 & \\
\hline ICPP-1782 & $\mathrm{pH}$ & $9 / 8 / 2008$ & 7.64 & \\
\hline ICPP-1783 & $\mathrm{pH}$ & $3 / 4 / 2008$ & 7.71 & \\
\hline ICPP-1783 & $\mathrm{pH}$ & $9 / 8 / 2008$ & 7.80 & \\
\hline ICPP-1800 & $\mathrm{pH}$ & $3 / 4 / 2008$ & 7.62 & \\
\hline ICPP-1800 & $\mathrm{pH}$ & $9 / 8 / 2008$ & 7.72 & \\
\hline ICPP-1829 & $\mathrm{pH}$ & $3 / 4 / 2008$ & 7.63 & \\
\hline ICPP-1829 & $\mathrm{pH}$ & $9 / 8 / 2008$ & 7.90 & \\
\hline ICPP-1831 & $\mathrm{pH}$ & $3 / 4 / 2008$ & 7.65 & \\
\hline ICPP-1831 & $\mathrm{pH}$ & 9/9/2008 & 7.88 & \\
\hline USGS-123 & $\mathrm{pH}$ & $3 / 4 / 2008$ & 7.97 & \\
\hline USGS-123 & $\mathrm{pH}$ & $9 / 8 / 2008$ & 7.97 & \\
\hline ICPP-1782 & Specific Conductivity & $3 / 4 / 2008$ & 0.441 & $\mathrm{mmhos} / \mathrm{cm}$ \\
\hline ICPP-1782 & Specific Conductivity & $9 / 8 / 2008$ & 0.425 & $\mathrm{mmhos} / \mathrm{cm}$ \\
\hline ICPP-1783 & Specific Conductivity & $3 / 4 / 2008$ & 0.508 & $\mathrm{mmhos} / \mathrm{cm}$ \\
\hline ICPP-1783 & Specific Conductivity & $9 / 8 / 2008$ & 0.484 & $\mathrm{mmhos} / \mathrm{cm}$ \\
\hline ICPP-1800 & Specific Conductivity & $3 / 4 / 2008$ & 0.554 & $\mathrm{mmhos} / \mathrm{cm}$ \\
\hline ICPP-1800 & Specific Conductivity & $9 / 8 / 2008$ & 0.537 & $\mathrm{mmhos} / \mathrm{cm}$ \\
\hline ICPP-1829 & Specific Conductivity & $3 / 4 / 2008$ & 0.678 & $\mathrm{mmhos} / \mathrm{cm}$ \\
\hline ICPP-1829 & Specific Conductivity & $9 / 8 / 2008$ & 0.627 & $\mathrm{mmhos} / \mathrm{cm}$ \\
\hline ICPP-1831 & Specific Conductivity & $3 / 4 / 2008$ & 0.439 & $\mathrm{mmhos} / \mathrm{cm}$ \\
\hline ICPP-1831 & Specific Conductivity & $9 / 9 / 2008$ & 0.436 & $\mathrm{mmhos} / \mathrm{cm}$ \\
\hline USGS-123 & Specific Conductivity & $3 / 4 / 2008$ & 0.375 & $\mathrm{mmhos} / \mathrm{cm}$ \\
\hline USGS-123 & Specific Conductivity & $9 / 8 / 2008$ & 0.357 & $\mathrm{mmhos} / \mathrm{cm}$ \\
\hline ICPP-1782 & Temperature & $3 / 4 / 2008$ & 12.46 & ${ }^{\circ} \mathrm{C}$ \\
\hline ICPP-1782 & Temperature & $9 / 8 / 2008$ & 13.13 & ${ }^{\circ} \mathrm{C}$ \\
\hline ICPP-1783 & Temperature & $3 / 4 / 2008$ & 12.72 & ${ }^{\circ} \mathrm{C}$ \\
\hline ICPP-1783 & Temperature & $9 / 8 / 2008$ & 13.81 & ${ }^{\circ} \mathrm{C}$ \\
\hline ICPP-1800 & Temperature & $3 / 4 / 2008$ & 12.25 & ${ }^{\circ} \mathrm{C}$ \\
\hline ICPP-1800 & Temperature & $9 / 8 / 2008$ & 14.23 & ${ }^{\circ} \mathrm{C}$ \\
\hline ICPP-1829 & Temperature & $3 / 4 / 2008$ & 9.02 & ${ }^{\circ} \mathrm{C}$ \\
\hline ICPP-1829 & Temperature & $9 / 8 / 2008$ & 13.74 & ${ }^{\circ} \mathrm{C}$ \\
\hline ICPP-1831 & Temperature & $3 / 4 / 2008$ & 12.07 & ${ }^{\circ} \mathrm{C}$ \\
\hline ICPP-1831 & Temperature & $9 / 9 / 2008$ & 13.09 & ${ }^{\circ} \mathrm{C}$ \\
\hline USGS-123 & Temperature & $3 / 4 / 2008$ & 12.32 & ${ }^{\circ} \mathrm{C}$ \\
\hline USGS-123 & Temperature & $9 / 8 / 2008$ & 13.42 & ${ }^{\circ} \mathrm{C}$ \\
\hline
\end{tabular}


B-4 


\section{Appendix C}

Analytical Results from 2008 Sampling of ICDF Aquifer Monitoring Wells 


$$
\text { C-2 }
$$




\section{Appendix C}

\section{Analytical Results from 2008 Sampling of ICDF Aquifer Monitoring Wells}

Table C-1. Analytical results for radionuclides.

\begin{tabular}{|c|c|c|c|c|c|c|c|c|c|c|c|c|}
\hline SDG Number & $\begin{array}{l}\text { Sample } \\
\text { Number }\end{array}$ & $\begin{array}{c}\text { Date } \\
\text { Collected }\end{array}$ & Location & Result Type & $\begin{array}{c}\text { Standard } \\
\text { Constituent }\end{array}$ & Concentration & $\begin{array}{l}\text { Combined } \\
\text { Standard } \\
\text { Uncertainty }\end{array}$ & $\begin{array}{c}\text { Lab } \\
\text { Qualifier }\end{array}$ & $\begin{array}{l}\text { Validation } \\
\text { Qualifier }\end{array}$ & Units & $\begin{array}{l}\text { Detection } \\
\text { Limit }\end{array}$ & $\begin{array}{c}\text { L\&V } \\
\text { Report } \\
\text { Number }\end{array}$ \\
\hline AWB12501R9 & AWB13101R9 & $3 / 4 / 08$ & ICDF & Field Blank & $\begin{array}{l}\text { Uranium- } \\
233 / 234 \\
\end{array}$ & 0.182 & 0.0701 & & $\mathrm{~J}$ & $\mathrm{PCI} / \mathrm{L}$ & 0.0782 & $\begin{array}{l}\text { DNT- } \\
138-08 \\
\end{array}$ \\
\hline AWB12501R9 & AWB12602R9 & $3 / 4 / 08$ & ICPP-1782 & $\begin{array}{l}\text { Field } \\
\text { Duplicate }\end{array}$ & $\begin{array}{l}\text { Uranium- } \\
233 / 234\end{array}$ & 1.95 & 0.273 & & & $\mathrm{PCI} / \mathrm{L}$ & 0.085 & $\begin{array}{l}\text { DNT- } \\
138-08\end{array}$ \\
\hline AWB12501R9 & AWB12601R9 & $3 / 4 / 08$ & ICPP-1782 & & $\begin{array}{l}\text { Uranium- } \\
233 / 234\end{array}$ & 1.85 & 0.26 & & & $\mathrm{PCI} / \mathrm{L}$ & 0.131 & $\begin{array}{l}\text { DNT- } \\
138-08 \\
\end{array}$ \\
\hline AWB12501R9 & AWB12701R9 & $3 / 4 / 08$ & ICPP-1783 & & $\begin{array}{l}\text { Uranium- } \\
233 / 234\end{array}$ & 1.7 & 0.233 & & & $\mathrm{PCI} / \mathrm{L}$ & 0.115 & $\begin{array}{l}\text { DNT- } \\
138-08\end{array}$ \\
\hline AWB12501R9 & AWB12801R9 & $3 / 4 / 08$ & ICPP-1800 & & $\begin{array}{l}\text { Uranium- } \\
233 / 234\end{array}$ & 1.32 & 0.198 & & & $\mathrm{PCI} / \mathrm{L}$ & 0.112 & $\begin{array}{l}\text { DNT- } \\
138-08\end{array}$ \\
\hline AWB12501R9 & AWB12901R9 & $3 / 4 / 08$ & ICPP-1829 & & $\begin{array}{l}\text { Uranium- } \\
233 / 234\end{array}$ & 1.34 & 0.204 & & & $\mathrm{PCI} / \mathrm{L}$ & 0.118 & $\begin{array}{l}\text { DNT- } \\
138-08\end{array}$ \\
\hline AWB12501R9 & AWB12501R9 & $3 / 4 / 08$ & ICPP-1831 & & $\begin{array}{l}\text { Uranium- } \\
233 / 234\end{array}$ & 1.89 & 0.252 & & & $\mathrm{PCI} / \mathrm{L}$ & 0.0745 & $\begin{array}{l}\text { DNT- } \\
138-08\end{array}$ \\
\hline AWB12501R9 & AWB13001R9 & $3 / 4 / 08$ & USGS-123 & & $\begin{array}{l}\text { Uranium- } \\
233 / 234 \\
\end{array}$ & 1.34 & 0.208 & & & $\mathrm{PCI} / \mathrm{L}$ & 0.195 & $\begin{array}{l}\text { DNT- } \\
138-08 \\
\end{array}$ \\
\hline AWB14101R9 & AWB14201R9 & $9 / 8 / 08$ & ICPP-1782 & & $\begin{array}{l}\text { Uranium- } \\
233 / 234\end{array}$ & 1.8 & 0.428 & & & $\mathrm{PCI} / \mathrm{L}$ & 0.128 & $\begin{array}{l}\text { BAM- } \\
034-08\end{array}$ \\
\hline AWB14101R9 & AWB14301R9 & $9 / 8 / 08$ & ICPP-1783 & & $\begin{array}{l}\text { Uranium- } \\
233 / 234\end{array}$ & 1.77 & 0.43 & & & $\mathrm{PCI} / \mathrm{L}$ & 0.14 & $\begin{array}{l}\text { BAM- } \\
034-08\end{array}$ \\
\hline AWB14101R9 & AWB14401R9 & $9 / 8 / 08$ & ICPP-1800 & & $\begin{array}{l}\text { Uranium- } \\
233 / 234\end{array}$ & 1.63 & 0.387 & & & $\mathrm{PCI} / \mathrm{L}$ & 0.108 & $\begin{array}{l}\text { BAM- } \\
034-08\end{array}$ \\
\hline AWB14101R9 & AWB14501R9 & $9 / 8 / 08$ & ICPP-1829 & & $\begin{array}{l}\text { Uranium- } \\
233 / 234\end{array}$ & 1.72 & 0.428 & & & $\mathrm{PCI} / \mathrm{L}$ & 0.1 & $\begin{array}{l}\text { BAM- } \\
034-08\end{array}$ \\
\hline
\end{tabular}


Table C-1. (continued).

\begin{tabular}{|c|c|c|c|c|c|c|c|c|c|c|c|c|}
\hline SDG Number & $\begin{array}{l}\text { Sample } \\
\text { Number }\end{array}$ & $\begin{array}{c}\text { Date } \\
\text { Collected }\end{array}$ & Location & Result Type & $\begin{array}{c}\text { Standard } \\
\text { Constituent }\end{array}$ & Concentration & $\begin{array}{l}\text { Combined } \\
\text { Standard } \\
\text { Uncertainty }\end{array}$ & $\begin{array}{c}\text { Lab } \\
\text { Qualifier }\end{array}$ & $\begin{array}{l}\text { Validation } \\
\text { Qualifier }\end{array}$ & Units & $\begin{array}{l}\text { Detection } \\
\text { Limit }\end{array}$ & $\begin{array}{c}\text { L\&V } \\
\text { Report } \\
\text { Number }\end{array}$ \\
\hline AWB14101R9 & AWB14701R9 & 9/8/08 & INEEL & Field Blank & $\begin{array}{l}\text { Uranium- } \\
233 / 234\end{array}$ & 0.0527 & 0.0912 & & $\mathrm{U}$ & $\mathrm{PCI} / \mathrm{L}$ & 0.158 & $\begin{array}{l}\text { BAM- } \\
034-08\end{array}$ \\
\hline AWB14101R9 & AWB14601R9 & $9 / 8 / 08$ & USGS-123 & & $\begin{array}{l}\text { Uranium- } \\
233 / 234\end{array}$ & 1.5 & 0.38 & & & $\mathrm{PCI} / \mathrm{L}$ & 0.104 & $\begin{array}{l}\text { BAM- } \\
034-08\end{array}$ \\
\hline AWB14101R9 & AWB14101R9 & 9/9/08 & ICPP-1831 & & $\begin{array}{l}\text { Uranium- } \\
233 / 234\end{array}$ & 2.11 & 0.461 & & & $\mathrm{PCI} / \mathrm{L}$ & 0.115 & $\begin{array}{l}\text { BAM- } \\
034-08\end{array}$ \\
\hline AWB14101R9 & AWB14102R9 & 9/9/08 & ICPP-1831 & $\begin{array}{l}\text { Field } \\
\text { Duplicate }\end{array}$ & $\begin{array}{l}\text { Uranium- } \\
233 / 234\end{array}$ & 1.89 & 0.431 & & & $\mathrm{PCI} / \mathrm{L}$ & 0.114 & $\begin{array}{l}\text { BAM- } \\
034-08\end{array}$ \\
\hline AWB12501R9 & AWB13101R9 & $3 / 4 / 08$ & ICDF & Field Blank & $\begin{array}{l}\text { Uranium- } \\
238\end{array}$ & 0.0198 & 0.0268 & & $\mathrm{U}$ & $\mathrm{PCI} / \mathrm{L}$ & 0.125 & $\begin{array}{l}\text { DNT- } \\
138-08\end{array}$ \\
\hline AWB12501R9 & AWB12602R9 & $3 / 4 / 08$ & ICPP-1782 & $\begin{array}{l}\text { Field } \\
\text { Duplicate }\end{array}$ & $\begin{array}{l}\text { Uranium- } \\
238\end{array}$ & 0.906 & 0.172 & & & $\mathrm{PCI} / \mathrm{L}$ & 0.085 & $\begin{array}{l}\text { DNT- } \\
138-08 \\
\end{array}$ \\
\hline AWB12501R9 & AWB12601R9 & $3 / 4 / 08$ & ICPP-1782 & & $\begin{array}{l}\text { Uranium- } \\
238\end{array}$ & 0.534 & 0.128 & & & $\mathrm{PCI} / \mathrm{L}$ & 0.151 & $\begin{array}{l}\text { DNT- } \\
138-08\end{array}$ \\
\hline AWB12501R9 & AWB12701R9 & $3 / 4 / 08$ & ICPP-1783 & & $\begin{array}{l}\text { Uranium- } \\
238\end{array}$ & 0.846 & 0.155 & & & $\mathrm{PCI} / \mathrm{L}$ & 0.147 & $\begin{array}{l}\text { DNT- } \\
138-08 \\
\end{array}$ \\
\hline AWB12501R9 & AWB12801R9 & $3 / 4 / 08$ & ICPP-1800 & & $\begin{array}{l}\text { Uranium- } \\
238\end{array}$ & 0.904 & 0.158 & & & $\mathrm{PCI} / \mathrm{L}$ & 0.112 & $\begin{array}{l}\text { DNT- } \\
138-08 \\
\end{array}$ \\
\hline AWB12501R9 & AWB12901R9 & $3 / 4 / 08$ & ICPP-1829 & & $\begin{array}{l}\text { Uranium- } \\
238\end{array}$ & 0.705 & 0.141 & & & $\mathrm{PCI} / \mathrm{L}$ & 0.118 & $\begin{array}{l}\text { DNT- } \\
138-08 \\
\end{array}$ \\
\hline AWB12501R9 & AWB12501R9 & $3 / 4 / 08$ & ICPP-1831 & & $\begin{array}{l}\text { Uranium- } \\
238\end{array}$ & 0.77 & 0.148 & & & $\mathrm{PCI} / \mathrm{L}$ & 0.0745 & $\begin{array}{l}\text { DNT- } \\
138-08 \\
\end{array}$ \\
\hline AWB12501R9 & AWB13001R9 & $3 / 4 / 08$ & USGS-123 & & $\begin{array}{l}\text { Uranium- } \\
238\end{array}$ & 0.873 & 0.16 & & & $\mathrm{PCI} / \mathrm{L}$ & 0.12 & $\begin{array}{l}\text { DNT- } \\
138-08\end{array}$ \\
\hline AWB14101R9 & AWB14201R9 & 9/8/08 & ICPP-1782 & & $\begin{array}{l}\text { Uranium- } \\
238\end{array}$ & 0.812 & 0.277 & & $\mathrm{~J}$ & $\mathrm{PCI} / \mathrm{L}$ & 0.0939 & $\begin{array}{l}\text { BAM- } \\
034-08\end{array}$ \\
\hline AWB14101R9 & AWB14301R9 & $9 / 8 / 08$ & ICPP-1783 & & $\begin{array}{l}\text { Uranium- } \\
238\end{array}$ & 0.724 & 0.263 & & $\mathrm{~J}$ & $\mathrm{PCI} / \mathrm{L}$ & 0.0612 & $\begin{array}{l}\text { BAM- } \\
034-08\end{array}$ \\
\hline AWB14101R9 & AWB14501R9 & $9 / 8 / 08$ & ICPP-1829 & & $\begin{array}{l}\text { Uranium- } \\
238\end{array}$ & 0.701 & 0.264 & & $\mathrm{~J}$ & $\mathrm{PCI} / \mathrm{L}$ & 0.1 & $\begin{array}{l}\text { BAM- } \\
034-08\end{array}$ \\
\hline
\end{tabular}


Table C-1. (continued).

\begin{tabular}{|c|c|c|c|c|c|c|c|c|c|c|c|c|}
\hline SDG Number & $\begin{array}{l}\text { Sample } \\
\text { Number }\end{array}$ & $\begin{array}{c}\text { Date } \\
\text { Collected }\end{array}$ & Location & Result Type & $\begin{array}{c}\text { Standard } \\
\text { Constituent }\end{array}$ & Concentration & $\begin{array}{l}\text { Combined } \\
\text { Standard } \\
\text { Uncertainty }\end{array}$ & $\begin{array}{c}\text { Lab } \\
\text { Qualifier }\end{array}$ & $\begin{array}{c}\text { Validation } \\
\text { Qualifier }\end{array}$ & Units & $\begin{array}{c}\text { Detection } \\
\text { Limit }\end{array}$ & $\begin{array}{c}\mathrm{L} \& \mathrm{~V} \\
\text { Report } \\
\text { Number }\end{array}$ \\
\hline AWB14101R9 & AWB14701R9 & $9 / 8 / 08$ & INEEL & Field Blank & $\begin{array}{l}\text { Uranium- } \\
238\end{array}$ & 0.0622 & 0.09 & & $\mathrm{U}$ & $\mathrm{PCI} / \mathrm{L}$ & 0.138 & $\begin{array}{l}\text { BAM- } \\
034-08 \\
\end{array}$ \\
\hline AWB14101R9 & AWB14601R9 & $9 / 8 / 08$ & USGS-123 & & $\begin{array}{l}\text { Uranium- } \\
238\end{array}$ & 0.629 & 0.239 & & $\mathrm{~J}$ & $\mathrm{PCL} / \mathrm{L}$ & 0.104 & $\begin{array}{l}\text { BAM- } \\
034-08 \\
\end{array}$ \\
\hline AWB14101R9 & AWB14101R9 & 9/9/08 & ICPP-1831 & & $\begin{array}{l}\text { Uranium- } \\
238\end{array}$ & 0.918 & 0.29 & & & $\mathrm{PCl} / \mathrm{L}$ & 0.0578 & $\begin{array}{l}\text { BAM- } \\
034-08 \\
\end{array}$ \\
\hline AWB14101R9 & AWB14102R9 & $9 / 9 / 08$ & ICPP-1831 & $\begin{array}{l}\text { Field } \\
\text { Duplicate }\end{array}$ & $\begin{array}{l}\text { Uranium- } \\
238\end{array}$ & 0.915 & 0.29 & & & $\mathrm{PCI} / \mathrm{L}$ & 0.114 & $\begin{array}{l}\text { BAM- } \\
034-08\end{array}$ \\
\hline
\end{tabular}


Table C-2. Analytical results for bicarbonate alkalinity and sulfate.

\begin{tabular}{|c|c|c|c|c|c|c|c|c|c|c|}
\hline SDG Number & $\begin{array}{l}\text { Sample } \\
\text { Number }\end{array}$ & $\begin{array}{c}\text { Date } \\
\text { Collected }\end{array}$ & Result Type & Location & Constituent & Concentration & $\begin{array}{c}\text { Lab } \\
\text { Qualifier }\end{array}$ & $\begin{array}{c}\text { Validation } \\
\text { Qualifier }\end{array}$ & Units & $\begin{array}{c}\text { L\&V Report } \\
\text { Number }\end{array}$ \\
\hline AWB12501B9 & AWB12901B9 & $3 / 4 / 08$ & & ICPP-1829 & Bicarbonate & 132 & & & $\mathrm{MG} / \mathrm{L}$ & DNT-146-08 \\
\hline AWB12501B9 & AWB13101B9 & $3 / 4 / 08$ & Field Blank & ICDF & Bicarbonate & 1.04 & $\mathrm{~J}$ & $\mathrm{U}$ & $\mathrm{MG} / \mathrm{L}$ & DNT-146-08 \\
\hline AWB12501B9 & AWB12801B9 & $3 / 4 / 08$ & & ICPP- 1800 & Bicarbonate & 141 & & & $\mathrm{MG} / \mathrm{L}$ & DNT-146-08 \\
\hline AWB12501B9 & AWB12701B9 & $3 / 4 / 08$ & & ICPP-1783 & Bicarbonate & 148 & & & $\mathrm{MG} / \mathrm{L}$ & DNT-146-08 \\
\hline AWB12501B9 & AWB12602B9 & $3 / 4 / 08$ & $\begin{array}{l}\text { Field } \\
\text { Duplicate }\end{array}$ & ICPP-1782 & Bicarbonate & 150 & & & $\mathrm{MG} / \mathrm{L}$ & DNT-146-08 \\
\hline AWB12501B9 & AWB12601B9 & $3 / 4 / 08$ & & ICPP-1782 & Bicarbonate & 152 & & & $\mathrm{MG} / \mathrm{L}$ & DNT-146-08 \\
\hline AWB12501B9 & AWB12501B9 & $3 / 4 / 08$ & & ICPP-1831 & Bicarbonate & 154 & & & $\mathrm{MG} / \mathrm{L}$ & DNT-146-08 \\
\hline AWB12501B9 & AWB13001B9 & $3 / 4 / 08$ & & USGS-123 & Bicarbonate & 130 & & & $\mathrm{MG} / \mathrm{L}$ & DNT-146-08 \\
\hline AWB14101B9 & AWB14601B9 & $9 / 8 / 08$ & & USGS-123 & Bicarbonate & 133 & & & $\mathrm{MG} / \mathrm{L}$ & DNT-391-08 \\
\hline AWB14101B9 & AWB14501B9 & $9 / 8 / 08$ & & ICPP-1829 & Bicarbonate & 132 & & & $\mathrm{MG} / \mathrm{L}$ & DNT-391-08 \\
\hline AWB14101B9 & AWB14401B9 & $9 / 8 / 08$ & & ICPP-1800 & Bicarbonate & 139 & & & $\mathrm{MG} / \mathrm{L}$ & DNT-391-08 \\
\hline AWB14101B9 & AWB14301B9 & $9 / 8 / 08$ & & ICPP-1783 & Bicarbonate & 151 & & & $\mathrm{MG} / \mathrm{L}$ & DNT-391-08 \\
\hline AWB14101B9 & AWB14201B9 & $9 / 8 / 08$ & & ICPP-1782 & Bicarbonate & 152 & & & $\mathrm{MG} / \mathrm{L}$ & DNT-391-08 \\
\hline AWB14101B9 & AWB14701B9 & $9 / 9 / 08$ & Field Blank & INEEL & Bicarbonate & 20 & & & $\mathrm{MG} / \mathrm{L}$ & DNT-391-08 \\
\hline AWB14101B9 & AWB14102B9 & $9 / 9 / 08$ & $\begin{array}{l}\text { Field } \\
\text { Duplicate }\end{array}$ & ICPP-1831 & Bicarbonate & 155 & & & $\mathrm{MG} / \mathrm{L}$ & DNT-391-08 \\
\hline AWB14101B9 & AWB14101B9 & 9/9/08 & & ICPP-1831 & Bicarbonate & 153 & & & $\mathrm{MG} / \mathrm{L}$ & DNT-391-08 \\
\hline AWB12501B9 & AWB13101S2 & $3 / 4 / 08$ & Field Blank & ICDF & Sulfate & 0 & $\mathrm{U}$ & & $\mathrm{MG} / \mathrm{L}$ & DNT-146-08 \\
\hline AWB12501B9 & AWB12602S2 & $3 / 4 / 08$ & $\begin{array}{l}\text { Field } \\
\text { Duplicate }\end{array}$ & ICPP-1782 & Sulfate & 22.5 & & & $\mathrm{MG} / \mathrm{L}$ & DNT-146-08 \\
\hline AWB12501B9 & AWB12501S2 & $3 / 4 / 08$ & & ICPP-1782 & Sulfate & 22.2 & & & $\mathrm{MG} / \mathrm{L}$ & DNT-146-08 \\
\hline AWB12501B9 & AWB12601S2 & $3 / 4 / 08$ & & ICPP-1782 & Sulfate & 22.4 & & & $\mathrm{MG} / \mathrm{L}$ & DNT-146-08 \\
\hline AWB12501B9 & AWB12701S2 & $3 / 4 / 08$ & & ICPP-1783 & Sulfate & 24.2 & & & $\mathrm{MG} / \mathrm{L}$ & DNT-146-08 \\
\hline AWB12501B9 & AWB12801S2 & $3 / 4 / 08$ & & ICPP- 1800 & Sulfate & 25.6 & & & $\mathrm{MG} / \mathrm{L}$ & DNT-146-08 \\
\hline AWB12501B9 & AWB12901S2 & $3 / 4 / 08$ & & ICPP-1829 & Sulfate & 27.4 & & & $\mathrm{MG} / \mathrm{L}$ & DNT-146-08 \\
\hline
\end{tabular}


Table C-2. (continued).

\begin{tabular}{|c|c|c|c|c|c|c|c|c|c|c|}
\hline SDG Number & $\begin{array}{l}\text { Sample } \\
\text { Number }\end{array}$ & $\begin{array}{c}\text { Date } \\
\text { Collected }\end{array}$ & Result Type & Location & Constituent & Concentration & $\begin{array}{c}\text { Lab } \\
\text { Qualifier }\end{array}$ & $\begin{array}{l}\text { Validation } \\
\text { Qualifier }\end{array}$ & Units & $\begin{array}{c}\text { L\&V Report } \\
\text { Number }\end{array}$ \\
\hline AWB12501B9 & AWB13001S2 & $3 / 4 / 08$ & & USGS-123 & Sulfate & 20 & & & $\mathrm{MG} / \mathrm{L}$ & DNT-146-08 \\
\hline AWB14101S2 & AWB14601S2 & $9 / 8 / 08$ & & USGS-123 & Sulfate & 22 & & & $\mathrm{MG} / \mathrm{L}$ & DNT-392-08 \\
\hline AWB14101S2 & AWB14501S2 & $9 / 8 / 08$ & & ICPP-1829 & Sulfate & 29.2 & & & $\mathrm{MG} / \mathrm{L}$ & DNT-392-08 \\
\hline AWB14101S2 & AWB14401S2 & $9 / 8 / 08$ & & ICPP- 1800 & Sulfate & 27.7 & & & $\mathrm{MG} / \mathrm{L}$ & DNT-392-08 \\
\hline AWB14101S2 & AWB14301S2 & $9 / 8 / 08$ & & ICPP-1783 & Sulfate & 26.3 & & & $\mathrm{MG} / \mathrm{L}$ & DNT-392-08 \\
\hline AWB14101S2 & AWB14201S2 & $9 / 8 / 08$ & & ICPP-1782 & Sulfate & 24.4 & & & $\mathrm{MG} / \mathrm{L}$ & DNT-392-08 \\
\hline AWB14101S2 & AWB14701S2 & $9 / 9 / 08$ & Field Blank & INEEL & Sulfate & 0.5 & $\mathrm{U}$ & & $\mathrm{MG} / \mathrm{L}$ & DNT-392-08 \\
\hline AWB14101S2 & AWB14102S2 & 9/9/08 & $\begin{array}{l}\text { Field } \\
\text { Duplicate }\end{array}$ & ICPP-1831 & Sulfate & 24.7 & & & $\mathrm{MG} / \mathrm{L}$ & DNT-392-08 \\
\hline AWB14101S2 & AWB14101S2 & 9/9/08 & & ICPP-1831 & Sulfate & 24.5 & & & $\mathrm{MG} / \mathrm{L}$ & DNT-392-08 \\
\hline
\end{tabular}

$\mathrm{J} \quad$ Flag from the laboratory means that the material was analyzed for, was detected at or above the applicable detection limit, and the associated value is an estimate that may be inaccurate or imprecise.

U Flag from the laboratory means that the material was not detected. 